\title{
Geochemical portray of the Pacific Ridge: New isotopic data and statistical techniques
}

\author{
Cédric Hamelin ${ }^{a,{ }^{*}}$, Laure Dosso ${ }^{b}$, Barry B. Hanan ${ }^{c}$, Manuel Moreira ${ }^{d}$, Andrew P. Kositsky ${ }^{e}$ and Marion \\ Y. Thomas
}

\author{
a I.U.E.M., U.B.O., Place Nicolas Copernic, 29280 Plouzané, France \\ ${ }^{\mathrm{b}}$ Centre National de la Recherche Scientifique, UMR 6538, IFREMER, BP70, 29280 Plouzané, \\ France \\ ${ }^{\mathrm{C}}$ Department of Geological Sciences, S.D.S.U., 5500 Campanile Drive, San Diego, CA 92182-1020, \\ USA \\ ${ }^{\mathrm{d}}$ Institut de Physique du Globe de Paris, CNRS UMR 7154, 1 rue Jussieu, 75252 Paris CEDEX 05, \\ France \\ ${ }^{\mathrm{e}}$ Tectonics Observatory, California Institute of Technology, Pasadena, CA 91125, USA
}

\begin{abstract}
* Corresponding author: Cédric Hamelin, I.P.G.P, 1 rue Jussieu, Bureau 345, 75252 Paris CEDEX 05, France. Tel.: +33 1839576 72; fax: +33 17193 7710, email address : hamelin@ipgp.fr
\end{abstract}

\begin{abstract}
:
Samples collected during the PACANTARCTIC 2 cruise fill a sampling gap from $53^{\circ}$ to $41^{\circ} \mathrm{S}$ along the Pacific Antarctic Ridge (PAR). Analysis of $\mathrm{Sr}, \mathrm{Nd}, \mathrm{Pb}, \mathrm{Hf}$, and He isotope compositions of these new samples is shown together with published data from $66^{\circ} \mathrm{S}$ to $53^{\circ} \mathrm{S}$ and from the EPR. The recent advance in analytical mass spectrometry techniques generates a spectacular increase in the number of multidimensional isotopic data for oceanic basalts. Working with such multidimensional datasets generates a new approach for the data interpretation, preferably based on statistical analysis techniques.

Principal Component Analysis (PCA) is a powerful mathematical tool to study this type of datasets. The purpose of PCA is to reduce the number of dimensions by keeping only those characteristics that contribute most to its variance. Using this technique, it becomes possible to have a statistical picture of the geochemical variations along the entire Pacific Ridge from $70^{\circ} \mathrm{S}$ to $10^{\circ} \mathrm{S}$. The incomplete sampling of the ridge led previously to the identification of a large-scale division of the south Pacific mantle at the latitude of Easter Island. The PCA method applied here to the completed dataset reveals a different geochemical profile. Along the Pacific Ridge, a large-scale bell-shaped variation with an extremum at about $38^{\circ} \mathrm{S}$ of latitude is interpreted as a progressive change in the geochemical characteristics of the depleted matrix of the mantle. This Pacific Isotopic Bump (PIB) is also noticeable in the He isotopic ratio along-axis variation. The linear correlation observed between $\mathrm{He}$ and heavy radiogenic isotopes, together with the result of the PCA calculation, suggests that the large-scale variation is unrelated to the plume-ridge interactions in the area and should rather be attributed to the partial melting of a marble-cake assemblage.
\end{abstract}

\section{Research Highlights}

New $\mathrm{Sr}, \mathrm{Nd}, \mathrm{Pb}, \mathrm{Hf}$, and $\mathrm{He}$ isotopes data fill a sampling gap along the Pacific Ridge. $\rightarrow \mathrm{We}$ examine geochemical variation in MORB using a principal component analysis. A progressive 
change in the depleted matrix is recognized along the Pacific ridge. In samples devoid of plume influence, $\mathrm{He}$ isotopes correlates with $\mathrm{Pb}$ isotopes.

Keywords: oceanic basalts; Pacific-Antarctic Ridge; mantle heterogeneity; Principal Component Analysis; $\mathrm{Sr} \mathrm{Nd} \mathrm{Pb} \mathrm{Hf} \mathrm{isotopes}$ 


\section{Introduction}

Mid-oceanic ridge basalts (MORB) are the result of continuous melting of the ambient upper mantle beneath oceanic ridges. The MORB-source mantle is generally thought to have been depleted $\sim 2$ Gy ago by extraction of the continents. Although the range of geochemical variations in oceanic basalts is mostly attributed to the influence of Ocean Island Basalt (OIB), significant geochemical heterogeneity in MORB has been recognized (Hoffman et al., 2003 and reference therein; Rudge et al., 2005). This heterogeneity has been revealed using radiogenic isotope ratios $(\mathrm{Sr}, \mathrm{Nd}, \mathrm{Pb}$ and $\mathrm{Hf})$ in areas devoid of plume influence. Numerous studies have attempted to model the mixing relationship between enriched and depleted domains within the mantle to reproduce the range of isotopic variations observed in oceanic basalts (Albarède, 2001; Meibom and Anderson, 2004; Rudge et al., 2005; Kellogg et al., 2007). The range of $\mathrm{Sr}, \mathrm{Nd}$ and $\mathrm{Pb}$ isotopic compositions depends not only on the endmember compositions but also on the volume of mantle sampled during the melting relative to the length scale of heterogeneities (Kellogg et al., 2007). Therefore, the range of MORB geochemical variations reflects the size, the spatial distribution, and the difference of fusibility of heterogeneities within the upper mantle. In addition to this intrinsic heterogeneity of the MORB mantle, radiogenic isotope studies have led to the definition of distinct broad mantle isotopic domains, such as the archetypal DUPAL anomaly located in the south hemisphere (Dupré and Allègre, 1983; Castillo, 1988). Boundaries between these domains can be (i) extremely sharp as seen at the Antarctic Australian-Antarctic Discordance (ADD), with isotopic ratios ( $\mathrm{Sr}, \mathrm{Nd}, \mathrm{Pb}$ and $\mathrm{Hf}$ ) abruptly changing from Indian to Pacific values (Pyle et al., 1992, Hanan et al., 2004; Meyzen et al., 2007; Cooper et al., 2009) or (ii) more gradual as seen in the transition from Southwest Indian Ridge to South Atlantic MORB (Meyzen et al, 2005). 
Another example of these large geochemical provinces is given by the two sub-pacific mantle domains (Vlastélic et al., 1999). The distinctive isotopic properties of these large-scale geochemical domains suggest a long-term isolation of these mantle provinces, each with their own convective histories involving various amounts of melting residues and recycled components. On the basis of an incomplete dataset, a boundary between these two pacific provinces has been located at the latitude of the Easter Island microplate (Vlastélic et al., 1999). But in order to have a complete geochemical view of the southern Pacific Ridge from 66 to $10^{\circ} \mathrm{S}$, it was necessary to fill the sampling gap between $53^{\circ} \mathrm{S}$ and $41^{\circ} \mathrm{S}$. This became one of the main objectives of the PACANTARCTIC2 cruise which took place in 2004-05 (Dosso et al. 2005, Klingelhoefer et al., 2006, Moreira et al., 2008; Hamelin et al., 2010). Analyses of $\mathrm{Sr}, \mathrm{Nd}, \mathrm{Pb}, \mathrm{Hf}$ and $\mathrm{He}$ isotopic compositions of these new samples from the Pacific Antarctic Ridge (PAR) are compiled here together with published data from $66^{\circ} \mathrm{S}$ to $53^{\circ} \mathrm{S}$ and from the East Pacific Rise (EPR). Therefore it becomes possible to have a picture of the geochemical variations along the entire Pacific Ridge from $66^{\circ} \mathrm{S}$ to the $10^{\circ} \mathrm{S}$. Adapting a Principal Component Analysis (PCA) to incomplete datasets, we show a detailed portray of the geochemical variability of the Pacific Ridge.

\section{Data selection and analytical methods.}

\subsection{The Pacific Ridge database from 10 to $66^{\circ} \mathrm{S}$.}

Along the Pacific Ridge, the Chile Triple Junction at $35^{\circ} \mathrm{S} / 110^{\circ} \mathrm{W}$ separates the PAR from the EPR. The two pacific ridges show different geological settings: the full spreading rate increases along the PAR from $54 \mathrm{~mm} / \mathrm{yr}$ at $65^{\circ} \mathrm{S}$ to $100 \mathrm{~mm} / \mathrm{yr}$ at $35^{\circ} \mathrm{S}$ whereas it decreases along the EPR from $158 \mathrm{~mm} / \mathrm{yr}$ at $35^{\circ} \mathrm{S}$ to $146 \mathrm{~mm} / \mathrm{yr}$ at $10^{\circ} \mathrm{S}$. In conjunction, the ridge axis morphology changes from a valley to a dome north of $60^{\circ} \mathrm{S}$ along the PAR (Ondréas et al., 
2001), whereas the EPR is characterized by a uniform dome shaped morphology. Three plume-ridge interactions generate abnormal morphological structures along this section: Foundation $\left(\sim 38^{\circ} \mathrm{S}\right)$, Easter Island $\left(\sim 26^{\circ} \mathrm{S}\right)$ and $17^{\circ} \mathrm{S}$. They are recognized by a high ridge cross-sectional area (Klingelhöfer et al., 2006) and the presence of intense off-axis volcanic activity. Compared to the EPR, the Pacific Antarctic Ridge still remains geochemically poorly known. A large portion of this plate boundary has been previously surveyed (Lonsdale, 1994; Cande et al., 1995) but the northern part has only recently been sampled (Dosso et al., 2005; Moreira et al., 2008; Hamelin et al., 2010).

To generate a coherent database along the pacific ridges, on-axis samples analyzed for one or more isotopic ratios (Sr-Nd-Pb-Hf-He) are selected from $66^{\circ} \mathrm{S}$ to $10^{\circ} \mathrm{S}$ using our new isotope data (table 1) completed with the petrological database of the Lamont-Doherty Earth Observatory (http://www.petdb.org). In most cases when the reference values of the standards are reported, the data are normalized to the values of NBS987, 0.71025 for Sr, of JNdi-1, 0.512104 and La Jolla, 0.511852 for Nd, NBS981, ${ }^{206} \mathrm{~Pb} /{ }^{204} \mathrm{~Pb}=16.9373,{ }^{207} \mathrm{~Pb} /{ }^{204} \mathrm{~Pb}=15.4925$, ${ }^{208} \mathrm{~Pb} /{ }^{204} \mathrm{~Pb}=36.7054$, for $\mathrm{Pb}$ and $\mathrm{JMC} 475,0.282162$ for $\mathrm{Hf}$ (see http://georem.mpch$\underline{\text { mainz.gwdg.de/ for details and references).: }}$

\subsection{Analytical methods.}

\subsubsection{Double Spike Pb analyses along the PAR}

New high-resolution $\mathrm{Pb}$ analyses were carried out for samples collected during PACANTARCTIC1 (PAC1) and PACANTARCTIC2 (PAC2) cruises along PAR segments from $66^{\circ} \mathrm{S}$ to $56^{\circ} \mathrm{S}$ and from $53^{\circ} \mathrm{S}$ to $41^{\circ} \mathrm{S}$ respectively (Fig. 1, Table 1). Small chips from the inner part of the pillow lavas were handpicked to avoid altered surfaces that could be a potential source of $\mathrm{Pb}$ contamination. Powdered samples were leached with $6 \mathrm{M} \mathrm{HCl}$ at $140^{\circ} \mathrm{C}$ 
117 for an hour and then rinsed up to 6 times with ultrapure water prior to dissolution. Lead

118 separation was then performed on an anionic exchange resin. $\mathrm{Pb}$ analyses were performed at 119 Ifremer (Centre de Brest) on a Finnigan MAT 26x multicollector instrument (MAT261

120 upgraded by Spectromat), using the double spike technique with the calibrated Southampton-

121 Brest 207/204 spike (Ishizuka et al., 2003). Replicate analyses of the $\mathrm{Pb}$ isotope standard

122 NBS981 gave an average of $16.9432 \pm 0.0027$ and $15.5004 \pm 0.0029$ and $36.7326 \pm 0.0086$ for $123{ }^{206} \mathrm{~Pb} /{ }^{204} \mathrm{~Pb},{ }^{207} \mathrm{~Pb} /{ }^{204} \mathrm{~Pb}$ and ${ }^{208} \mathrm{~Pb} /{ }^{204} \mathrm{~Pb}$, respectively. $\mathrm{Pb}$ blanks measured using this 124 procedure were $<100 \mathrm{pg}$, and thus negligible relative to the amount of sample analyzed.

\subsubsection{Hf measurements along the PAR}

Hafnium isotopic compositions were analyzed along the PAC1 ridge segments at SDSU on splits from the same samples (Hamelin et al., 2010). Hf was separated using the protocol of Blichert-Toft et al. 1997 with a negligible blank of less than 25 pg. Hf isotope ratios were

130 measured at SDSU using the $\mathrm{Nu}$ Plasma. The ${ }^{176} \mathrm{Hf} /{ }^{177} \mathrm{Hf}$ was normalized for mass

131 fractionation relative to ${ }^{179} \mathrm{Hf} /{ }^{177} \mathrm{Hf}=0.7325$. The JMC-475 $\mathrm{Hf}$ standard ${ }^{176} \mathrm{Hf} /{ }^{177} \mathrm{Hf}$ gave $1320.282160 \pm 0.000010(2 \sigma)$ during this study. The standard was run alternately with samples to 133 monitor machine performance.

\subsubsection{He measurements along the PAR}

136 Helium isotopic compositions have been measured on PAC1 and PAC2 samples at IPGP

137 (Institut de Physique du Globe de Paris). Fresh pieces of glass were cleaned with distilled 138 water, ethanol and acetone using an ultrasonic bath. Some samples were also cleaned with 139 hydrogen peroxide in order to remove some $\mathrm{Mg}$ crust. Analytical procedure is identical to 140 previous studies from our laboratory and can be found in Moreira et al. (1995). Samples were 141 crushed under vacuum with analytical blanks of $7 \pm 1$ nccSTP ${ }^{4} \mathrm{He}$. This corresponds to 0.02 to 
$1420.4 \%$ of the samples. Helium concentrations and isotopic composition were measured using

143 the ARESIBOII mass spectrometer (Moreira et al., 2008).

145 3. New results compared to published MORB data along this

146 ridge section.

147

148

149

150

151

152

153

154

155

156

157

158

159

160

161

162

163

164

These results include samples from $66^{\circ} \mathrm{S}$ to $56^{\circ} \mathrm{S}$ (PAC1) and from $53^{\circ} \mathrm{S}$ to $41^{\circ} \mathrm{S}$ (PAC2)

(Fig. 1). New high resolution $\mathrm{Pb}$ analyses as well as $\mathrm{Hf}$ and $\mathrm{He}$ analyses are presented here in Table 1. The Sr, Nd and Hf analyses on the same samples are found in Vlastélic et al. (2000) and Hamelin et al. (2010).

\subsection{Binary isotopic correlations}

With 7 isotopic ratios, the number of possible binary isotope diagrams is 21 . As an example, we choose here to describe 4 such binary plots, selecting some of the most commonly discussed (Fig. 2A-D). In all diagrams, pacific MORB samples devoid of plume influence define linear correlations that in most cases have been previously described in the literature. This result is in good agreement with the expected coherence in behavior between $\mathrm{Rb}-\mathrm{Sr}, \mathrm{U}-\mathrm{Pb}$, Th- $\mathrm{Pb}, \mathrm{Sm}-\mathrm{Nd}$ and $\mathrm{Lu}-\mathrm{Hf}$ isotopic systems compared to each other during magmatic processes. When plume-ridge interaction samples are included in our dataset, they define elongated fields overlapping PAR-EPR array except in Figure $2 \mathrm{C}$ where $\mathrm{He}-\varepsilon_{\mathrm{Nd}}$ isotopic ratios define sub-parallel trends which emerge from the PAR-EPR array and point towards higher ${ }^{3} \mathrm{He} /{ }^{4} \mathrm{He}(\mathrm{R} / \mathrm{Ra})$ ratios. More than 30 years of $\mathrm{He}$ isotopes systematic of oceanic basalts worldwide have shown that MORB samples are characterized by a narrow 
165

166

range of composition compared to OIB samples. However even within this limited range, our data show a linear correlation between ${ }^{3} \mathrm{He} /{ }^{4} \mathrm{He}(\mathrm{R} / \mathrm{Ra})$ values and $\varepsilon_{\mathrm{Nd}}$ (Fig. 2C). The correlation between $\mathrm{He}$ and other isotopic systems will be discussed further below (\$4.4.2).

In contrast with the decoupling of $\mathrm{Hf}$ and $\mathrm{Nd}$ isotope compositions previously documented in MORB (e.g., Patchett and Tatsumoto, 1980; Salters and White, 1998; Chauvel et al., 2001; Debaille et al., 2006), a rather good correlation between these two isotopic systems is observed along our studied are (Fig. 2B). Debaille et al. (2006) have suggested that a distinctive behavior of $\mathrm{Hf}$ during disequilibrium melting along their studied ride area (Atlantic ridge $22-35^{\circ} \mathrm{N}$ ) could explain a decoupled behavior of ${ }^{176} \mathrm{Hf} /{ }^{177} \mathrm{Hf}$ with respect to other isotopic ratios. The linear correlations observed in our dataset, show that the hypothesis of a specific behavior of $\mathrm{Hf}$ does not apply along the pacific ridges. Recently, good correlations between $\mathrm{Hf}$ and $\mathrm{Nd}$ isotopic ratios have been reported from other ridge segments such as Mohns Ridge (Blichert-Toft et al., 2005) and the entire mid-Atlantic Ridge (Agranier et al., 2005).

\subsection{MORB variability along the south Pacific Ridge.}

Latitudinal isotopic variations of south Pacific Ridge basalts are shown in Figure 3. An important geochemical feature from 66 to $10^{\circ} \mathrm{S}$ is a large scale (spanning approximately $5000 \mathrm{~km}$ ) and coherent variation of all isotopes shown by a bell shape grey line. The extremum of this variation defining the Pacific Isotopic Bump (PIB), is located at the latitude of Foundation $\left(38^{\circ} \mathrm{S}\right)$. It reveals a less depleted component, characterized by more radiogenic values for $\mathrm{Sr}, \mathrm{Pb}$ isotopic ratios, and correlatively less radiogenic values for $\mathrm{Nd}$ and $\mathrm{Hf}$. Three shorter wavelength variations of the order of 200 to $700 \mathrm{~km}$ are seen as isotopic anomalies superimposed on the otherwise bell shaped curve of the isotope signature along the ridge. In a way similar to the Pacific Isotopic Bump, these variations are towards more radiogenic Sr and 
$\mathrm{Pb}$ values and coherently less radiogenic $\mathrm{Nd}$ and $\mathrm{Hf}$ values. They indicate the influence of

191 enriched materials due to plume-ridge interactions.

192 Helium isotopes do not fit this $\mathrm{Sr}-\mathrm{Pb} / \mathrm{Hf}-\mathrm{Nd}$ coherent behavior. At the latitude of the

193 Foundation-Ridge intersection $\left(38^{\circ} \mathrm{S}\right)$, the bell-shaped $\mathrm{He}$ curve shows radiogenic ${ }^{3} \mathrm{He} /{ }^{4} \mathrm{He}$

194 ratios. But on the other hand, hot-spot influenced samples form negative "plume anomalies"

195 with very unradiogenic signatures (high ${ }^{3} \mathrm{He} /{ }^{4} \mathrm{He}$ ratios, up to $12 \mathrm{R} / \mathrm{Ra}$ ). The amplitudes of the

196 PIB and the anomalies attributed to the plume effect are of the same order of magnitude for

$197 \mathrm{Nd}$, Hf and $\mathrm{Pb}$. For $\mathrm{He}$ and $\mathrm{Sr}$, the PIB has much smaller amplitude than the hotspot

198 anomalies. Additionally, local MORB variability is expressed as spikes, which are likely

199 related to transform faults (Eltanin System).

201 4. Discussion

\subsection{Statistical definition of mantle reference lines}

In most binary plots of radiogenic isotopic ratios, representative points of mantle derived material define linear trends. Historically, these trends have been used to define reference lines such as the Northern Hemisphere Reference Line (NHRL) in Pb-Pb plot (Hart, 1984) or the "Mantle Array" in Sr-Nd plot (DePaolo and Wasserburg, 1979) and the Nd-Hf plot (Vervoort and Blichert-Toft, 1999). These reference lines are arbitrary and depend on the abundance of data available at the time of their definition. However, the data colinearity in these plots justifies these convenient choices. The NHRL has been convenient to quantify the

210 Dupal anomaly using the $\Delta 7 / 4$ and $\Delta 8 / 4$ (Hart, 1984). In 1999, new MORB data from the 211 south Pacific lead to the definition of the Pacific Reference Line (PRL) which proved 212 convenient to compare two sub-pacific mantle domains, using the $\delta(\mathrm{Nd}-\mathrm{Sr})$ and $\delta(\mathrm{Sr}-\mathrm{Pb})$ 213 notations (Vlastélic et al., 1999). With the recent advance in analytical MC-ICPMS 
214 techniques, the number of isotopic data increases dramatically. It becomes possible to look at 215 these reference lines in multidimensional space from a statistical point of view. Principal 216 Component Analysis (PCA) is a powerful mathematical tool to study data sets such as a 217 geochemical database including $\mathrm{Sr}-\mathrm{Nd}-\mathrm{Pb}-\mathrm{Hf}$ analyses. The purpose of PCA analysis is to 218 reduce the number of dimensions in a data set by keeping those characteristics that contribute 219 most to its variance. This technique has been used in previous mantle heterogeneity studies 220 (e.g. Agranier et al., 2005, Debaille et al., 2006) The PCA method used with our geochemical 221 dataset has been initially developed for low-rank matrix approximations (Srebro and Jaakkola, 222 2003) and was recently adapted for tectonic problems using incomplete geodetic times series 223 (Kositsky and Avouac, 2010). The main difference with traditional PCA methods is that the 224 singular value decomposition is replaced by a more sophisticated decomposition, which 225 appropriately takes into account samples with a missing isotope measurement. This technique is particularly suitable to geochemical data as it allows computing the principal components using the whole dataset, increasing therefore the accuracy of the calculation (see supplementary material for a more detailed discussion about the concept and the limits of our 229 calculation). Although more recently ICA (Independent Component Analysis) has been 230 chosen by some authors (Iwamori and Albarède, 2008, Iwamori et al., 2010), the preferred 231 PCA method used here has the advantage of dealing with missing isotopic data, assuming that 232 decorrelation is still a good assumption of independence in our dataset.

233 Because the PCA method is an orthogonal linear transformation, it assumes the linearity of 234 the data co-variations. In most binary isotopic diagrams, mixing processes are expressed by 235 hyperboles whose curvatures depend on the elemental concentration ratios of the involved 236 end-members. But in the case of MORB, pseudo-linear correlations are observed (Fig. 2) 237 indicating that denominator elements are in approximately constant proportions in the mixing 238 components. It is very difficult to evaluate the extent of non-linear relationships concealed 
within the analytical noise. However, it is worth noting that the geographical variations of the

240 components calculated with our method are approximately the same as those computed in the

241 3-dimensional space of $\mathrm{Pb}$ isotopes, in which relationships are linear. In order to minimize the

242 correlations induced by the ${ }^{204} \mathrm{~Pb}$ analytical noise (it represents only about $1.4 \%$ of the total

$243 \mathrm{~Pb}$ ), the computation has been made in the ${ }^{204} \mathrm{~Pb} /{ }^{206} \mathrm{~Pb},{ }^{207} \mathrm{~Pb} /{ }^{206} \mathrm{~Pb}$ and ${ }^{208} \mathrm{~Pb} /{ }^{206} \mathrm{~Pb}$ space.

244 Considering the problematic of our study, this observation suggests that the curvature can be

245 neglected. One drawback of PCA in general stems from the fact that PCA is a projection method, and sometimes low-dimensional visualization can lead to erroneous interpretations.

\subsection{Distribution of the variance among the principal components.}

The most striking result of the PCA is that the first principal component accounts for more than $70 \%$ of the total variance. This result is remarkable considering the number of geochemical parameters involved in the very large number of samples used in this analysis. It indicates the strong coherence of all isotopic ratios within the depleted mantle domain. These correlations in binary plots of isotopic systems are the result of two antagonistic processes that took place over time: chemical fractionation events leading to the existence of enriched and depleted mantle reservoirs and mechanical mixing of theses reservoirs during mantle convection. The chemical fractionation between parent and daughter isotopes is controlled by distribution coefficients. Even if these coefficients can be modified by multiple parameters, they remain consistent from one element to another. Since these processes are approximately linear, the resulting dispersion is located along a line corresponding to PC1 (the first Principal Component).

260 While the importance of the first component is indisputable, one challenge with PCA is to 261 establish the number of significant components needed to explain the observed data variance.

262 A classical way to illustrate the number of relevant components is to study the residual 263 variance $\left(\chi^{2}\right)$ obtained for each component (e.g. Kositsky and Avouac, 2010). This value 
drops abruptly after the third component (see supplementary material). At first, we can infer

265 that the information brought by the fourth to the sixth principal components is statistically insignificant and can safely be ignored. Using a PCA computed in the 3-dimensional space of $\mathrm{Pb}$ isotopes, the principal components account for $91.7 \%, 8.2 \%$ and $0.1 \%$ of the variance for PC1, PC2 and PC3 respectively. This observation suggests that the variance expressed by principal components over the order of 2 is the result of a randomly distributed error. Also the

270 absence of coherent geographical variation for the third component suggests that this variance 271 could either be a very local variation or an artifact of our data compilation (i.e. sampling bias, 272 data and error normalization between different laboratories). This justifies to limit the 273 discussion of the south pacific mantle heterogeneity to the PC1 and PC2 characteristics.

\subsection{Mapping geochemical heterogeneities in the mantle using a PCA method.}

Using the dataset available at the time, Vlastélic et al. (1999) identified a large geochemical variation in the south Pacific depleted mantle. Based on an incomplete sampling of the ridge, they suggested the existence of a sharp boundary located at the latitude of the

279 Easter Island Microplate $\left(27^{\circ} \mathrm{S}\right)$. As an interpretation, they proposed that the Pacific 280 Superswell divided the mantle into two domains each with their own convective histories, 281 producing slight differences in their average isotopic signatures. More recently, the origin of 282 these two domains has been challenged by a model based on plate kinetics (Small and 283 Danyushevsky, 2003). Small and Danyushevsky proposed that geochemical discontinuities 284 result from variations of the asthenosphere consumption, which corresponds to the ratio 285 between the accretion rate and the spreading center migration relative to plumes. Their model 286 predicted that the fast spreading, slowly migrating East Pacific Rise should have higher 287 average melting degrees compared to the slower spreading, rapidly migrating Pacific288 Antarctic Rise. In order to identify the two mantle domains along the Pacific Ridge, Vlastélic 
et al. (1999) used $\delta(\mathrm{Sr}-\mathrm{Pb})$ and $\delta(\mathrm{Nd}-\mathrm{Sr})$, which are defined as the vertical deviations from

290 references lines in $\mathrm{Pb}$ vs $\mathrm{Sr}$ and $\mathrm{Sr}$ vs $\mathrm{Nd}$ isotopic ratio plots respectively. These reference 291 lines (see §4.1) were drawn intuitively in the greatest variance of their dataset. They can be 292 directly compared to our first principal component. By construction, whatever the number of 293 dimensions considered in the PCA, the projection of PC1 in a binary diagram resembles the 294 relevant reference line (Fig. 2). Because PC2 is orthogonal to the greatest variance, sample 295 values along this component are correlated to delta notations such as $\delta(\mathrm{Sr}-\mathrm{Pb}), \delta(\mathrm{Nd}-\mathrm{Sr})$ or $296 \Delta 8 / 4 \mathrm{~Pb}$. But compared to delta notations, PC2 has the advantage of being rigorously and statistically determined in a multidimensional isotopic space. The application of the PCA method to our data compilation (excluding He isotopes) reveals a geochemical profile of the 299 Pacific Ridge. The plot of PC1 versus latitude summarizes all the characteristics noted with 300 the different isotopic systems (Fig. 4). The short scale geochemical variations associated with 301 hotspots as well as the large-scale variation are clearly visible. $17^{\circ} \mathrm{S}$ and $25^{\circ} \mathrm{S}$ (Easter Island) are well defined by sharp anomalies superimposed on the bell shaped curve. A plot of PC2 versus latitude shows a very different picture (Fig. 4): only the large scale variation is 304 expressed by this component, the geochemical variations associated with hotspots are 305 flattened and the corresponding samples are projected along the bell shape curve defining the 306 Pacific Isotopic Bump. This PIB is also shown on plots of delta versus latitude, illustrating the 307 equivalence of these parameters and PC2 (Fig. 4). At the Juan Fernandez/Foundation latitude $308\left(36^{\circ} \mathrm{S}\right)$, the isotopic variation curve reaches an extreme which corresponds to a less "depleted" 309 isotopic signature. In contrast with the conclusion of Vlastélic et al. (1999), we proposed that 310 geochemical variations along the Pacific Ridge are not the result of two separated mantle 311 domains but should rather be seen as a progressive variation of the isotopic composition of the 312 sub-Pacific depleted mantle. Since the asthenosphere consumption varies abruptly at the Chile 313 triple junction and is almost constant along the PAR, the plate kinematic model of Small and 
314 Danyushevsky (2003) is also inconsistent with the observed progressive variation of the 315 MORB depleted matrix. interactions.

\subsubsection{Asthenospheric versus hotspots signals as illustrated by $\mathrm{Sr}-\mathrm{Nd}-\mathrm{Pb}-\mathrm{Hf}$.}

Except in figures involving He isotopes, geochemical variations related to ridge/hotspot interactions are consistent with variations of samples devoid of plume influence. At first, it is

322 difficult to distinguish the two types of variations in binary isotopic plots (Fig. 2). 323 Nevertheless, a PCA computed with all heavy radiogenic isotopes clearly illustrate a 324 difference: hotspot signatures are exclusively visible with $\mathrm{PC} 1$, while the variance related to 325 the large scale variation (PIB) is illustrated by both PC1 and PC2 versus latitude (Fig. 4). In 326 PC1 versus PC2 space, the MORB field extends from the depleted end member of the mantle 327 (DMM) toward a recycled oceanic crust end member with a HIMU affinity (Fig. 5). The 328 samples identified as resulting from a plume-ridge interaction are not part of this "depleted 329 trend". Rather their data field extends from the depleted trend towards more enriched-type 330 end members such as $\mathrm{C}$ and/or EM. This observation supports the idea that the large scale 331 variation in the depleted Pacific mantle is unrelated to ridge/hotspot interactions. This 332 variation is therefore equivalent to the intrinsic variability of MORB recognized in other areas 333 (e.g. Dosso et al., 1999, Donnelly et al., 2004; Debaille et al., 2006; Hémond et al., 2006). It 334 has to be noted that PCA calculations assume a linearity criteria which is not satisfied when 335 dealing with isotopic compositions of the mantle end-members. It is thus not possible to 336 determine more precisely the nature of the different mantle components responsible for the 337 observed trends. Nevertheless, the PCA calculations establish that the progressive 
geochemical change of the depleted matrix of the Pacific mantle is not the result of hotspot material being diluted into the depleted mantle. Using a different approach, Meyzen et al.

340 (2007) successfully unscrambled the hotspot and asthenospheric signals. These authors have

341 proposed that the geochemical variations unrelated to ridge/hotspot interactions along the

342 South West Indian ridge and the South Atlantic ridge are related to a broad lower mantle 343 upwelling in this area. Similarly, a broad lower mantle input could be a plausible cause of the

344 Pacific Isotopic Bump associated with the high spreading rates in the vicinity of the Chile 345 Ridge Triple junction.

346 It is interesting to compare the results of our PCA calculation along the Pacific ridge with 347 the spectral analysis performed along the Atlantic ridge by Agranier et al. (2005). These 348 authors found two contrasting types of spectra along their study area. The first type is 349 associated with ridge-hotspot interactions and is seen in the first principal component. The 350 second type is illustrated by the continuous power decrease with the decreasing wavelength of 351 the second principal component. Agranier et al. (2005) have interpreted this second type of 352 spectra, unrelated to hotspots, as being the result of the continuous size reduction of mantle 353 heterogeneities upon stretching and refolding of the convecting mantle. Despite the 354 differences in geological settings between the Pacific ridge and the Atlantic ridge, our 355 observations are in good agreement with the statistical analysis of Agranier et al. (2005). We 356 view the PIB as the consequence of a progressive change in the relative proportions of the 357 marble-cake components present in the Pacific upper mantle. In this model, hotspot anomalies 358 are superimposed on the intrinsic mantle heterogeneity expressed in MORB.

4.4.2. He isotopes in the depleted mantle compared to hotspot signals.

361 Unlike other isotopic systems, helium shows a first order discrepancy between the hotspot 362 and the depleted mantle signals in our studied area (Fig. 3 and Fig. 6): the large scale variation 
associated to the depleted mantle is characterized by an increase towards more radiogenic

364 (low ${ }^{3} \mathrm{He} /{ }^{4} \mathrm{He}$ ) compositions, whereas the short scale variation associated to the mantle plumes points towards high ${ }^{3} \mathrm{He} /{ }^{4} \mathrm{He}$ values as previously noted in Hanan and Graham (1996). The origin of the large range of elevated ${ }^{3} \mathrm{He} /{ }^{4} \mathrm{He}$ values in OIB lavas is a long-lived controversial question (Kurz et al., 1982; Allègre et al., 1983; Meibom et al., 2003; Moreira et al., 2004). Historically, the requirement of a high ${ }^{3} \mathrm{He} /{ }^{4} \mathrm{He}$ reservoir for the OIB lead to the idea that 369 plumes are tapping a deep, undegassed lower mantle, isolated from the upper mantle convection (O’Nions et al., 1996; Allègre et al., 1997). Numerous alternative models have tried to solve the apparent inconsistency between the high ${ }^{3} \mathrm{He} /{ }^{4} \mathrm{He}$ ratio in plumes and the requirement of a source previously processed through partial melting (e.g. Parman et al., 2005; Class and Goldstein, 2005; Purtika, 2008; Albarède, 2008; Davies, 2010).

Compared to plume-influenced samples, systematics of He isotopes in depleted MORB samples have shown a very restricted range of ${ }^{3} \mathrm{He} /{ }^{4} \mathrm{He}$ with a peak of distribution around $8 \pm 1$ (R/Ra) (Allègre et al., 1995). Within the uncontaminated depleted mantle sampled along our 377 studied area, ${ }^{3} \mathrm{He} /{ }^{4} \mathrm{He}$ varies from 6 to $9.5(\mathrm{R} / \mathrm{Ra})$. Samples devoid of plume influence fall 378 along a negative trend toward low ${ }^{3} \mathrm{He} /{ }^{4} \mathrm{He}$ values and high ${ }^{206} \mathrm{~Pb} /{ }^{204} \mathrm{~Pb}$. This variation of $\mathrm{He}$ 379 isotopes in our samples devoid of plume influence is clearly related to the PIB identified 380 along the pacific ridge using $\mathrm{PCA}$ with $\mathrm{Sr}, \mathrm{Nd}, \mathrm{Pb}$ and $\mathrm{Hf}$ isotopes. It is interesting to note 381 that the most enriched samples from this correlation show the lowest ${ }^{3} \mathrm{He} /{ }^{4} \mathrm{He}$ values (more 382 radiogenic). In order to reconcile the ${ }^{3} \mathrm{He} /{ }^{4} \mathrm{He}$ variations with variations of $\mathrm{Sr}, \mathrm{Pb}, \mathrm{Nd}$ and $\mathrm{Hf}$ 383 isotopes, new models take into account the physical specificities of He compared to heavy 384 radiogenic isotopes: its diffusivity in mantle conditions and its capacity to be outgassed from 385 melts at sub-surface pressure (e.g. Hart et al., 2008; Albarède et al., 2008; Gonnermann and 386 Mukhopadhyay, 2009). We propose that the melting of a marble-cake upper mantle, 387 unpolluted by plumes, produces the good correlation observed between $\mathrm{He}$ and $\mathrm{Pb}$ isotopes in 
our depleted samples. The less depleted component of the mantle assemblage is characterized by a high $\mathrm{Pb}$ isotopic ratio and a low ${ }^{3} \mathrm{He} /{ }^{4} \mathrm{He}$ ratio. We suggest that this component was derived from the recycling of an extensively outgassed oceanic crust. When the oceanic crust

407 ridge interaction. is subducted back into the mantle, it contains negligible concentration of mantle-derived $\mathrm{He}$ (Staudacher and Allègre, 1988). With time, this very low ${ }^{3} \mathrm{He} /(\mathrm{U}+\mathrm{Th})$ in subducted slabs is expected to produce the end-member with high $\mathrm{Pb}$ isotopes value and low ${ }^{3} \mathrm{He} /{ }^{4} \mathrm{He}$ ratio (Fig. $6)$.

In our model, the variation of $\mathrm{He}$ isotopes along the pacific ridge could be interpreted as: (1) a smaller contribution of the refractory layers (less radiogenic), corresponding to a lower ${ }^{3} \mathrm{He} /{ }^{4} \mathrm{He}$ ratio at the PIB but because the melting rate is expected to be higher near the Chile Ridge Triple Junction, this hypothesis seems very unlikely, or (2) a higher volume of the recycled end-member in this area. This hypothesis is in agreement with the conclusions derived from the PCA based on heavy radiogenic isotopes (§4.4.1). The intrinsic geochemical variation of the depleted upper mantle comforts the image of a marble cake mantle composed of a refractory component and a recycled oceanic crust component. A broad volume of recycled component associated with the high spreading rates in the vicinity of the Chile Ridge Triple junction is therefore a plausible cause of the Pacific Isotopic Bump. The correlation between $\mathrm{He}$ and $\mathrm{Pb}$ isotopes revealed by our new data (Fig. 6) suggests that the depleted mantle is the outcome of a mixing of a different nature that the one involved in the plume- 


\section{Conclusion}

411 Analyses of this new sampling of the PAR complete the dataset of the Pacific Ridge.

412 Therefore it becomes possible to have a picture of the geochemical variations from 10 to

$41370^{\circ} \mathrm{S}$. Our data show a clear geographical evolution of isotopic characteristics along the

414 Pacific Ridge. In binary isotopic plots, this large-scale variation is expressed by correlations

415 between each isotopic dimension. This observation holds true even for the $\mathrm{Nd}-\mathrm{Hf}$ system

416 previously reported as decoupled for MORB samples (Debaille et al., 2006). Even more

417 significant in this study is the linear correlation shown in the isotopic $\mathrm{He}-\mathrm{Nd}$ and ${ }^{3} \mathrm{He} /{ }^{4} \mathrm{He}$ -

$418{ }^{206} \mathrm{~Pb} /{ }^{204} \mathrm{~Pb}$ plots. In these isotopic spaces, the samples affected by plume-ridge interactions

419 depart clearly from the linear correlations displayed by the ridge samples coming from the

420 depleted mantle.

421 Despite the paucity of combined $\mathrm{Sr}-\mathrm{Nd}-\mathrm{Pb}-\mathrm{Hf}$ isotope data on individual samples, the PCA

422 algorithms used here allow us to portray the variation along a huge section of the Pacific

423 Ridge from a statistical point of view. Compared to previous studies of the sub-Pacific

424 mantle, the application of PCA reveals a Pacific Isotopic Bump, which can be seen as a 425 progressive geochemical variation of the depleted upper-mantle matrix rather than a sharp 426 frontier between two mantle domains. Combining PCA results with the information given by 427 He isotopes, we suggest that the Pacific Isotopic Bump is unrelated to plume-ridge 428 interactions. This geochemical variation in the upper mantle reservoir is the result of a 429 marble-cake mantle assemblage composed of a residual mantle component and a recycled 430 oceanic crust component. 


\section{Acknowledgements}

433 The $\mathrm{Pb}$ isotope work was funded by CNRS/INSU. The Hf isotope work was supported by 434 NSF grants to B.B. Hanan. We thank Joan Miller for technical assistance at SDSU. We 435 acknowledge Rick Carlson for the editorial handling, Francis Albarède and an anonymous 436 reviewer for constructive comments. Cedric Hamelin thanks the Caltech Tectonic 437 Observatory for its hospitality during his stay in Pasadena. We gratefully acknowledge Neus 438 Sabater for her valuable comments. 


\section{References}

Agranier, A., Blichert-Toft, J., Graham, D., Debaille, V., Schiano, P., Albarede, F., 2005. The spectra of isotopic heterogeneities along the mid-Atlantic Ridge. Earth Planet. Science Lett., 238(1-2): 96-109.

Albarède, F., 2001. Radiogenic ingrowth in systems with multiple reservoirs: applications to the differentiation of the mantle-crust system. Earth Planet. Science Lett., 189(1-2): 59-73.

Albarède, F., 2008. Rogue mantle Helium and Neon. Science, 319: 943-945.

Allègre, C.J., Staudacher, T., Sarda, P., Kurz, M., 1983. Constraints on evolution of the earth's mantle from rare gas systematic. Nature, 303: 762-766.

Allegre, C.J., Moreira, M., Staudacher, T., 1995. 4He/3He dispersion and mantle convection. Geophysical Research Letters, 22(17): 2325-2328.

Allègre, C.J., 1997. Limitation on the mass exchange between the upper and lower mantle: the evolving convection regime of the Earth. Earth Planet. Science Lett., 150(1-2): 1-6.

Blichert-Toft, J., Albarède, F., 1999. Hf isotopic compositions of the Hawaii Scientific Drilling Project core and the source mineralogy of Hawaiian basalts. Geophys. Res. Lett., 26(7): 935-938.

Blichert-Toft, J., Agranier, A., Andres, M., Kingsley, R., Schilling, J.-G., Albarède, F., 2005. Geochemical segmentation of the Mid-Atlantic Ridge north of Iceland and ridge-hot spot interaction in the North Atlantic. Geochem. Geophys. Geosyst., 6(1): Q01E19.

Cande, S.C., Raymond, C.A., Stock, J. and Haxby, W.F., 1995. Geophysics of the Pitman fracture zone and Pacific-Antarctic plate motions during the Cenozoic. Science, 270: 947-953.

Chauvel, C., Blichert-Toft, J., 2001. A hafnium isotope and trace element perspective on melting of the depleted mantle. Earth Planet. Science Lett., 190(3-4): 137-151.

Class, C., Goldstein, S., 2005. Evolution of helium isotopes in the Earth's mantle. Nature, 436(25): 1107-1112.

Class, C., 2008. Hot arguments to cool off the plume debate? Geology, 36(4): 335-336.

Cooper, K.M., Eiler, J.M., Sims, K.W.W., Langmuir, C.H., 2009. Distribution of recycled crust within the upper mantle: Insights from the oxygen isotope composition of MORB from the Australian-Antarctic Discordance. Geochem. Geophys. Geosyst., 10. 
Davis, 2010. Noble gases in the dynamic mantle. Geochem. Geophys. Geosyst., 11(3): Q03005.

Debaille, V., Blichert-Toft, J., Agranier, A., Doucelance, R., Schiano, P., Albarède, F., 2006. Geochemical component relationships in MORB from the Mid-Atlantic Ridge, 22$35^{\circ}$ N. Earth Planet. Science Lett., 241(3-4): 844-862.

DePaolo, D.J., Wasserburg, G.J., 1979. Sm-Nd age of the Stillwater complex and the mantle evolution curve for neodymium. Geochim. Cosmochim. Acta, 43: 999-1008.

Dosso, L., Bougault, H., Langmuir, C., Bollinger, C., Bonnier, O., Etoubleau, J.,.. (1999). The age and distribution of mantle heterogeneity along the Mid-Atlantic Ridge $\left(31-41^{\circ} \mathrm{N}\right)$. Earth Planet. Science Lett., 170: 269-286.

Dosso, L., Ondréas, H., Briais, A., Fernagu, P., Floch, G., Hamelin, C., Hanan, B.B., Klingelhoefer, F., Moreira, M., Normand, A., 2005. The Pacific-Antarctic Ridge between $41^{\circ} 15^{\prime} \mathrm{S}$ and $52^{\circ} 45^{\prime} \mathrm{S}$ : Survey and sampling during the PACANTARCTIC 2 cruise. InterRidge News, 14: 1-5.

Dupré, B., Allègre, C.J., 1983. Pb-Sr isotope variation in Indian Ocean basalts and mixing phenomena. Nature, 303: 142-146.

Farley, K.A., Neroda, E., 1998. Noble gases in the Earth's mantle. Annual Review of Earth and Planetary Sciences, 26: 189-218.

Gonnermann, H.M., Mukhopadhyay, S., 2009. Preserving noble gases in a convecting mantle. Nature, 459: 560-563.

Hamelin, C., Dosso, L., Hanan, B., Barrat, J.-A., Ondréas, H., 2010. Sr-Nd-Hf isotopes along the Pacific Antarctic Ridge from 41 to 53오. Geophys. Res. Lett., 37(10): L10303.

Hanan, B.B., Graham, D.W., 1996. Lead and Helium Isotope Evidence from Oceanic Basalts for a Common Deep Source of Mantle Plumes. Science, 272: 991-995.

Hanan, B.B., Blichert Toft, J., Pyle, D.G., Christie, D.M., 2004. Contrasting origins of the upper mantle revealed by hafnium and lead isotopes from the Southeast Indian Ridge. Nature, 432: 91-94.

Hart, S.R., 1984. A large scale isotope anomaly in the Southern Hemisphere mantle. Nature, 309: 753-757.

Hart, S.R., Kurz, M.D., Wang, Z., 2008. Scale length of mantle heterogeneities: Constraints from helium diffusion. Earth Planet. Science Lett., 269(3-4): 508-517.

Hémond, C., Hofmann, A.W., Vlastélic, I., Nauret, F., 2006. Origin of MORB enrichment and relative trace element compatibilities along the Mid-Atlantic Ridge between $10^{\circ}$ and $24^{\circ}$ N. Geochem. Geophys. Geosyst., 7, Q12010. 
Hofmann, A.W., 2003. Sampling mantle heterogeneity through oceanic basalts: Isotopes and trace elements. In: H. Holland and K.K. Turekian (Editors), Treatise on Geochemistry. Elsevier-Pergamon, Oxford, pp. 61-101.

Iwamori, H., Albarède, F., 2008. "Decoupled isotopic record of ridge and subduction zone processes in oceanic basalts by independent component analysis." Geochem. Geophys. Geosyst., 9.

Iwamori, H., Albarède, F., Nakamura, H., 2010. "Global structure of mantle isotopic heterogeneity and its implications for mantle differentiation and convection." Earth Planet. Science Lett., 299(3-4): 339-351.

Ishizuka, O., Taylor, R.N., Milton, J.A., Nesbitt, R.W., 2003. Fluid-mantle interaction in an intra-oceanic arc: constraints from high-precision $\mathrm{Pb}$ isotopes. Earth Planet. Science Lett., 211: 221-236.

Jackson, M.G., Hart, S.R., Saal, A.E., Shimizu, N., Kurz, M.D., Blusztajn, J.S., Skovgaard, A.C., 2008. Globally elevated titanium, tantalum, and niobium (TITAN) in ocean island basalts with high 3He/4He. Geochem. Geophys. Geosyst., 9(4): 1-21.

Jackson, M.G., Kurz, M.D., Hart, S.R., 2009. Helium and neon isotopes in phenocrysts from Samoan lavas: Evidence for heterogeneity in the terrestrial high He-3/He-4 mantle. Earth Planet. Science Lett., 287(3-4): 519-528.

Kellogg, J.B., Jacobsen, S.B., O'Connell, R.J., 2007. Modeling lead isotopic heterogeneity in mid-ocean ridge basalts. Earth Planet. Science Lett., 262(3-4): 328-342.

Klein, E.M., Langmuir, C.H., Zindler, A., Staudigel, H., Hamelin, B., 1988. Isotope evidence of a mantle convection boundary at the Australian-Antartic discordance. Nature, 333: 623-629.

Klingelhoefer, F., Ondréas, H., Briais, A., Hamelin, C., Dosso, L., 2006. New structural and geochemical observations from the Pacific-Antarctic Ridge $52^{\circ} 45^{\prime} \mathrm{S}$ and $41^{\circ} 15^{\prime} \mathrm{S}$. Geophys. Res. Lett., 33.

Kositsky, A.P., Avouac, J.P., 2010. Inverting geodetic time series with a principal component analysis-based inversion method. J. Geophys. Res., 115(B3): B03401.

Kurz, M.D., Jenkins, W.J., Hart, S.R., 1982. Helium isotopic systematics of oceanic islands and mantle heterogeneity. Nature, 297: 43-47.

Lonsdale, P., 1994. Geomorphology and structural segmentation of the crest of the southern (Pacific-Antarctic) East Pacific Rise. J. Geophys. Res., 99(B3): 4683-4702. 
Meibom, A., Anderson, D.L., Sleep, N.H., Frei, R., Chamberlain, C.P., Hren, M.T., Wooden, J.L., 2003. Are high $3 \mathrm{He} / 4 \mathrm{He}$ ratios in oceanic basalts an indicator of deep-mantle plume components? Earth Planet. Science Lett., 208(3-4): 197-204.

Meibom, A., Anderson, D.L., 2004. The statistical upper mantle assemblage. Earth Planet. Science Lett., 217(1-2): 123-139.

Meyzen, C.M., Ludden, J.N., Humler, E., Luais, B., Toplis, M.J., Mével, C., Storey, M., 2005. New insights into the origin and distribution of the DUPAL isotope anomaly in the Indian Ocean mantle from MORB of the Southwest Indian Ridge. Geochem. Geophys. Geosyst., 6(11): 1-34.

Meyzen, C.M., Blichert-Toft, J., Ludden, J.N., Humler, E., Mevel, C., Albarede, F., 2007. Isotopic portrayal of the Earth/'s upper mantle flow field. Nature, 447(7148): 10691074.

Moreira, M., Staudacher, T., Sarda, P., Schilling, J.-G., Allègre, C.J., 1995. A primitive plume neon component in MORB: The Shona ridge-anomaly, South Atlantic (51-52 $\left.{ }^{\circ} \mathrm{S}\right)$, Earth Planet. Science Lett., 133, 367-377.

Moreira, M., Dosso, L., Ondréas, H., 2008. Helium isotopes on the Pacific-Antarctic ridge (52.5-41.5 S). Geophys. Res. Lett., 35(L10306): 1-6.

Ondréas, H., Aslanian, D., Géli, L., Olivet, J.-L. and Briais, A., 2001. Variations in axial morphology, segmentation, and seafloor roughness along the Pacific-Antarctic Ridge between $56^{\circ} \mathrm{S}$ and $66^{\circ} \mathrm{S}$. J. Geophys. Res., 106(B5): 8521-8546.

O’Nions, R.K., Peltier, W.R., Davies, J.H., Runcorn, S.K., 1996. Phase-transition modulated mixing in the mantle of the Earth - Discussion. Philosophical Transactions of the Royal Society of London Series A - Mathematical Physical and Engineering Sciences, 354(1711): 1443-1447.

Parman, S.W., Kurz, M.D., Hart, S.R., Grove, T.L., 2005. Helium solubility in olivine and implications for high 3He/4He in ocean island basalts. Nature, 437(7062): 1140-1143.

Patchett, P.J., Tatsumoto, M., 1980. Hafnium isotope variations in oceanic basalts. Geophys. Res. Lett., 7: 1077-1080.

Putirka, K., 2008. Excess temperatures at ocean islands: Implications for mantle layering and convection. Geology, 36(4): 283-286.

Pyle, D.G., Christie, D.M., Mahoney, J.J., 1992. Resolving an isotopic boundary within the Australian-Antarctic Discordance. Earth Planet. Science Lett., 112: 161-178. 
Rudge, J.F., McKenzie, D., Haynes, P.H., 2005. A theoretical approach to understanding the isotopic heterogeneity of mid-ocean ridge basalt. Geochim. Cosmochim. Acta, 69(15): 3873-3887.

Salters, V.J.M., White, W.M., 1998. Hf isotope constraints on mantle evolution. Chem. Geol., 145: 447-460.

Small, C., Danyushevsky, L.V., 2003. Plate-kinematic explanation for mid-oceanic-ridge depth discontinuities. Geology, 31(5): 399-402.

Srebro, N. N., Jaakkola T. 2003, Weighted low-rank approximations, paper presented at 20th International Conference on Machine Learning, Assoc. for the Adv. of Art. Intell., Washington, D. C.

Stracke, A., Bourdon, B., 2009. The importance of melt extraction for tracing mantle heterogeneity. Geochim. Cosmochim. Acta, 73(1): 218-238.

Starkey, N.A., Stuart, F.M., Ellam, R.M., Fitton, J.G., Basu, S., Larsen, L.M., 2009. Helium isotopes in early Iceland plume picrites: Constraints on the composition of high $\mathrm{He}$ 3/He-4 mantle. Earth Planet. Science Lett., 277(1-2): 91-100.

Staudacher, T., Allègre, C.J., 1988. Recycling of oceanic crust and sediments: the noble gas subduction barrier. Earth Planet. Science Lett., 89(2): 173-183.

Vlastélic, I., Aslanian, D., Dosso, L., Bougault, H., Olivet, J.L., Géli, L., 1999. Large-scale chemical and thermal division of the Pacific mantle. Nature, 399(6734): 345-350.

Vlastélic, I., Dosso, L., Bougault, H., Aslanian, D., Géli, L., Etoubleau, J., Bohn, M., Joron, J.L., Bollinger, C., 2000. Chemical systematics of an intermediate spreading ridge: The Pacific-Antarctic Ridge between $56^{\circ} \mathrm{S}$ and $66^{\circ} \mathrm{S}$. J. Geophys. Res., 105(B2): 2915-2936.

Vervoort, J.D, Blichert-Toft, J, 1999. Evolution of the depleted mantle: Hf isotope evidence from juvenile rocks through time, Geochim. Cosmochim. Acta, 63, 553-556. 


\section{Figure captions}

Figure 1: Map of the south pacific basin showing the location of the PACANTARCTIC1 and PACANTARCTIC2 cruises with respect to the Pacific Antarctic Ridge (PAR) and the East Pacific Rise (EPR). Hotspot locations are shown in orange on the map.

600

Figure 2: Examples of binary plots showing correlations within the MORB field. Samples 602 devoid of plume influence are shown in blue whereas samples from plume-ridge interactions are in red. Blue circles represent samples collected along the PAR and blue crosses for EPR samples (all symbols are kept the same in all figures). Mantle reference lines defined in the literature are shown in dashed lines: in the $\mathrm{Sr} / \mathrm{Nd}$ plot (A), the Pacific Reference Line (PRL) (Vlastélic et al., 1999), in the Nd/Hf plot (B), the mantle array (Vervoort et al., 1999), in the $\mathrm{Pb} / \mathrm{Pb}$ plot (D), the North Hemisphere Reference Line (NHRL) (Hart, 1984). Since no reference line had yet been recognized in plots involving He isotopes, we show here a regression line $\left({ }^{3} \mathrm{He} /{ }^{4} \mathrm{He}=0.63 \varepsilon_{\mathrm{Nd}}+1.74, \mathrm{r}=0.89\right)(\mathrm{C})$. The projection of the two first principal components (PC1 and PC2) calculated in our study are shown (solid black and grey

611 lines, see text for additional information). Data references can be found in supplementary 612 materials.

614 Figure 3: Geochemical variations along the PAR and the EPR from $66^{\circ} \mathrm{S}$ to $10^{\circ} \mathrm{S}$. Dashed 615 lines represent the location of major transform faults in the area and a grey shade is used for 616 the Juan Fernandez and Easter Island microplates. The grey curve underlines the large-scale 617 isotopic variation along the pacific ridges from 10 to $66^{\circ} \mathrm{S}$ and defines the Pacific Isotopic 618 Bump (PIB). 
620 Figure 4: Plot of the two first principal components along the Pacific Ridge. The similarity 621 between PC2 and $\delta$ notation is illustrated by plotting $\delta(\mathrm{Sr}-\mathrm{Pb})$ as defined by Vlastélic et al. 622 (1999) and $\Delta^{207} \mathrm{~Pb}$ as defined by Hart (1984) versus latitude.

623

624 Figure 5: Plot of PC2 versus PC1 for a principal component analysis computed using Sr, Nd, $625 \mathrm{Hf}$ and $\mathrm{Pb}$ isotopes. The hashed blue field defines the depleted trend and includes EPR and 626 PAR samples. Data points are drawn as ellipses representing the $95 \%$ confidence domain of 627 the components as calculated in Debaille et al. (2006). The insert shows the location of the 628 classical mantle end-members in the PC2 vs PC1 space.

629

630 Figure 6: Binary plot of ${ }^{3} \mathrm{He} /{ }^{4} \mathrm{He}$ vs ${ }^{206} \mathrm{~Pb} /{ }^{204} \mathrm{~Pb}$. The dashed regression line $\left({ }^{3} \mathrm{He} /{ }^{4} \mathrm{He}=-2.33\right.$ $\left.631{ }^{206} \mathrm{~Pb} /{ }^{204} \mathrm{~Pb}+51.0\right)$ is defined by samples devoid of plume influence. Plume-ridge interactions $632\left(17^{\circ} \mathrm{S}\right.$ and Easter hotspots) are characterized by positive trends emerging from the PAR-EPR 633 array and pointing towards higher ${ }^{3} \mathrm{He} /{ }^{4} \mathrm{He}(\mathrm{R} / \mathrm{Ra})$ ratios and higher ${ }^{206} \mathrm{~Pb} /{ }^{204} \mathrm{~Pb}$.

634

635 Table 1: Complete $\mathrm{Sr}, \mathrm{Nd}, \mathrm{Pb}, \mathrm{Hf}$ and He isotope data table for PACANTARCTIC 1 and 2 636 samples. In italic font, previously published data (Vlastélic et al., 1999; Vlastélic et al., 2000;

637 Moreira et al., 2008; Hamelin et al., 2010). 


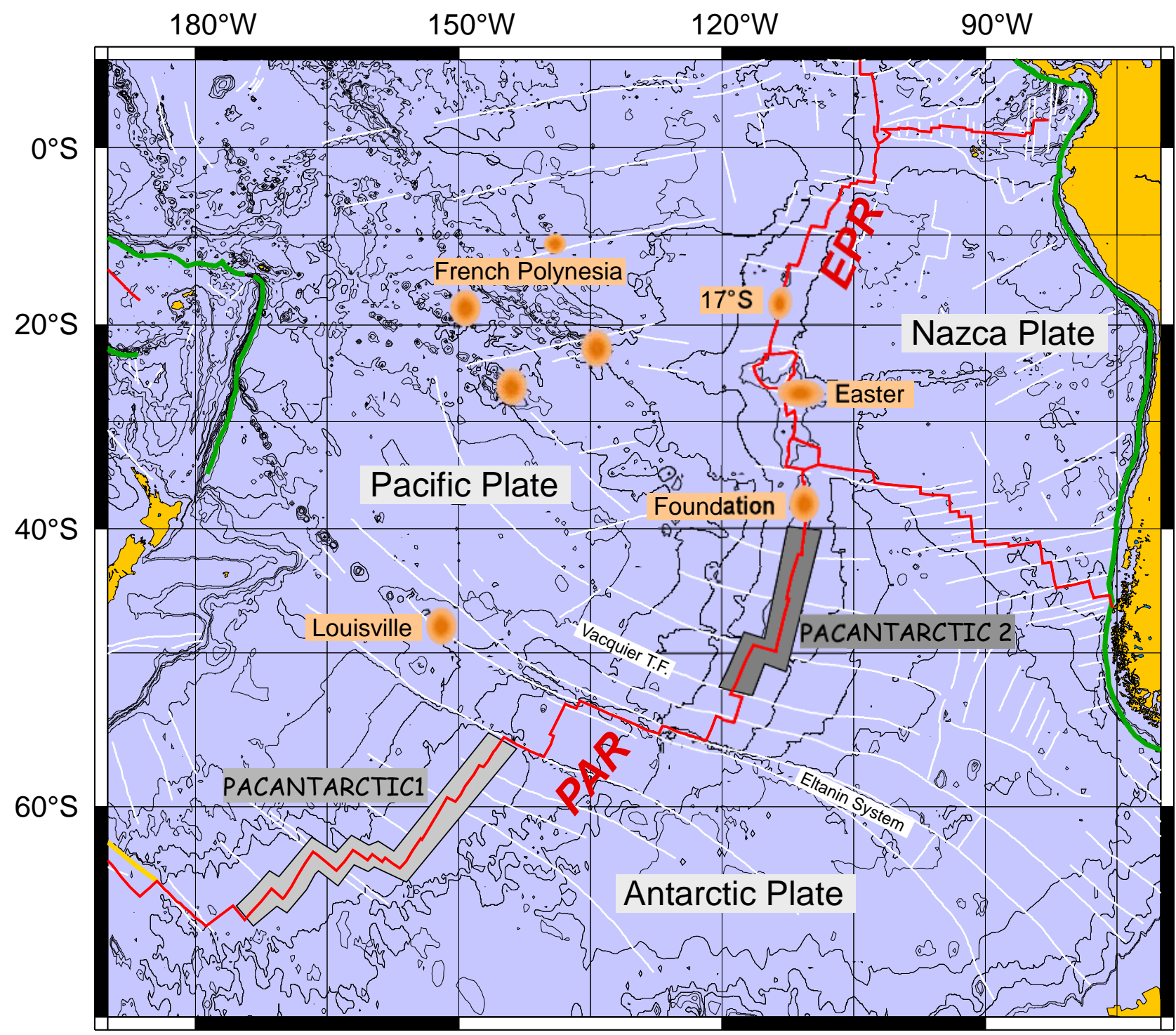



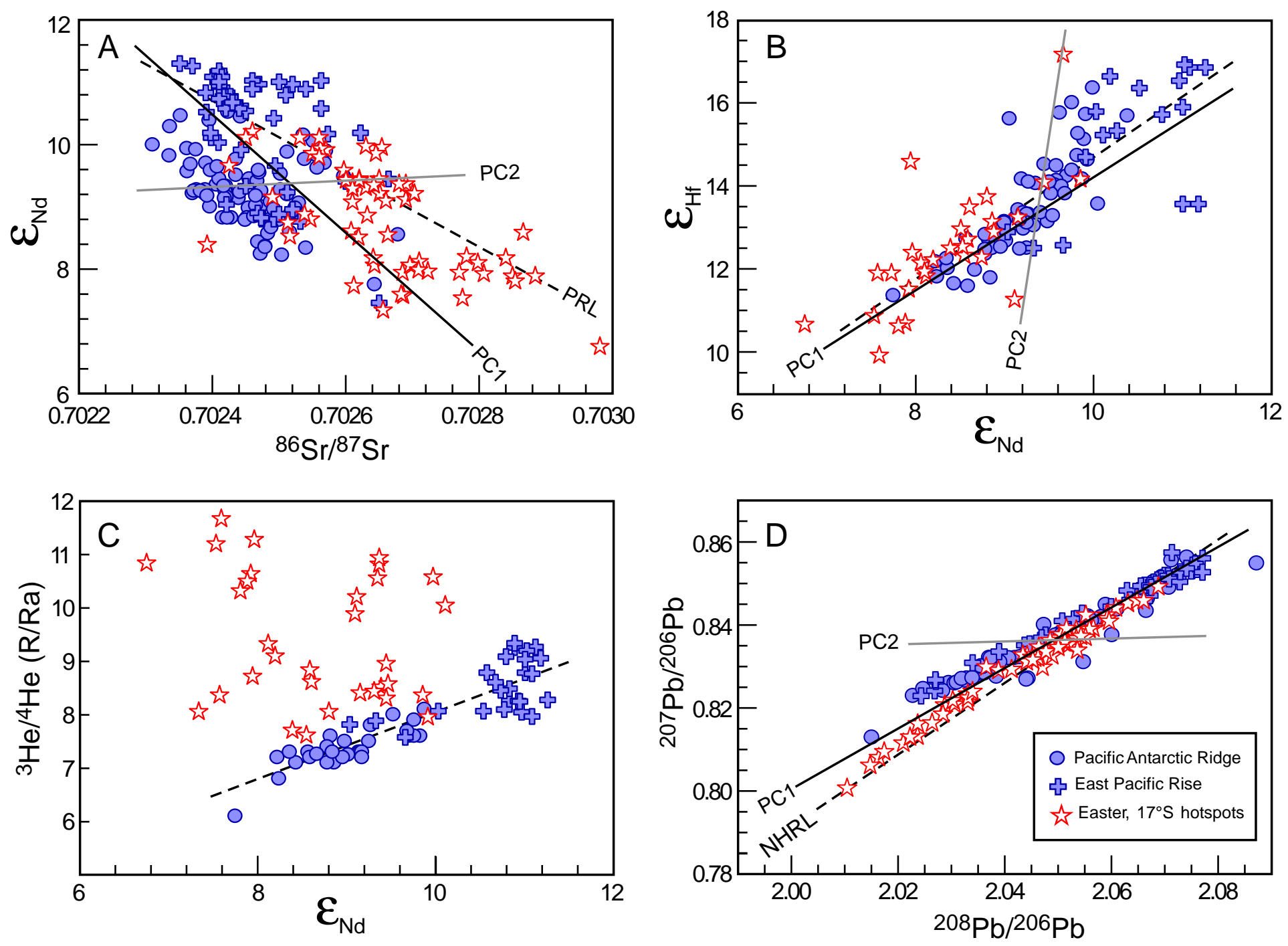


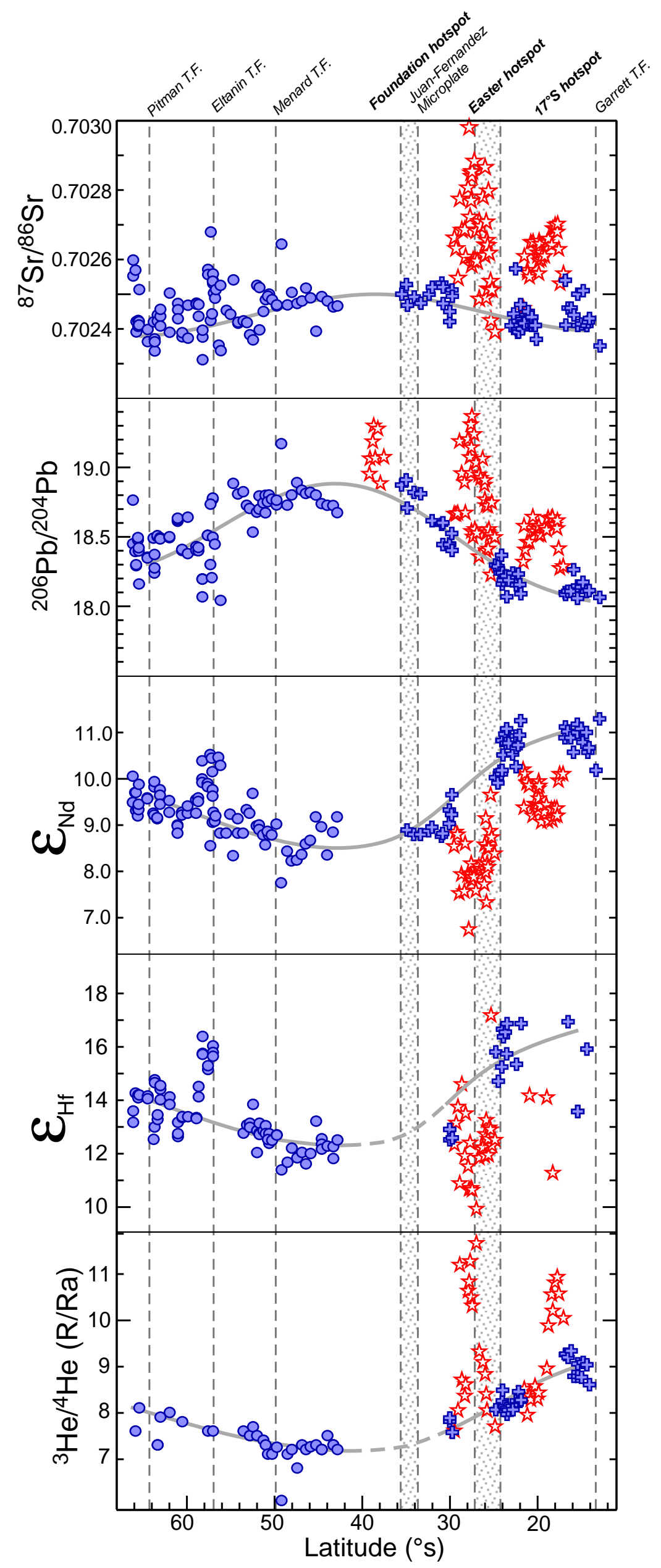




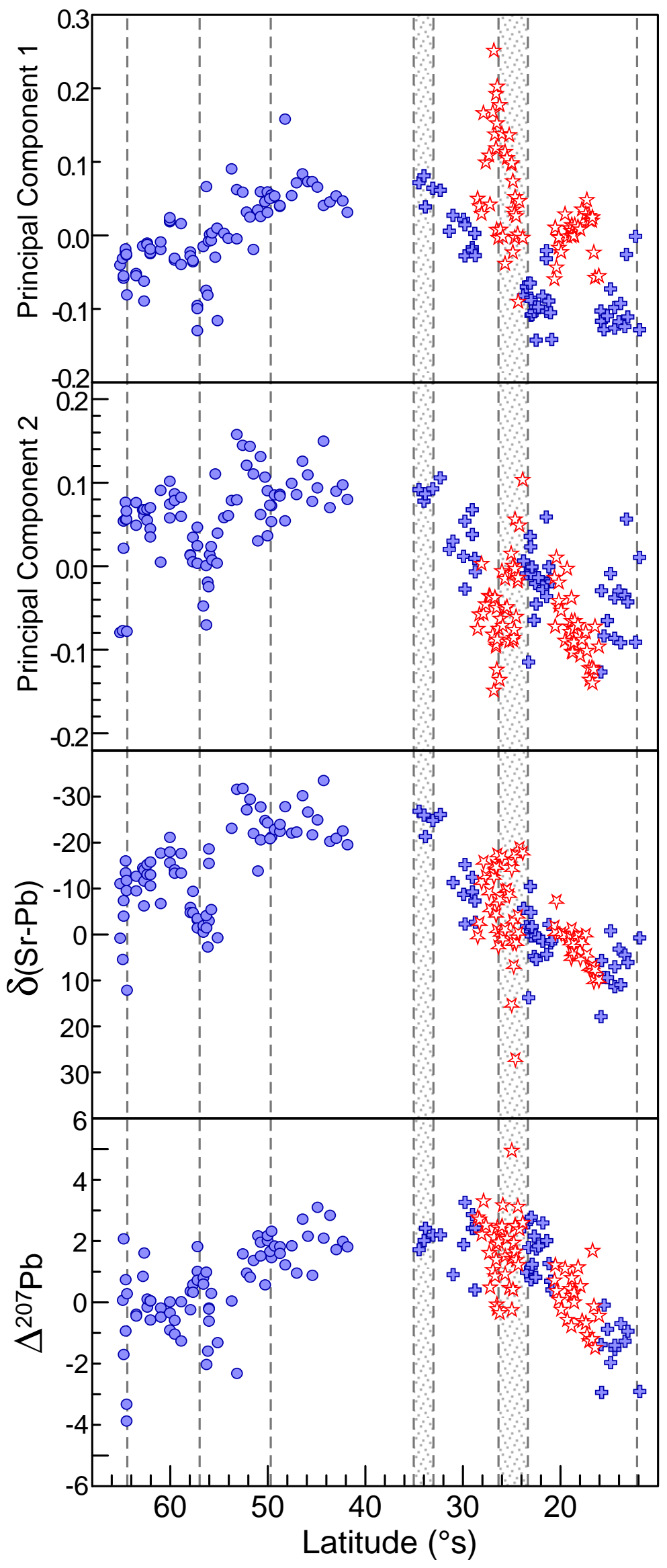




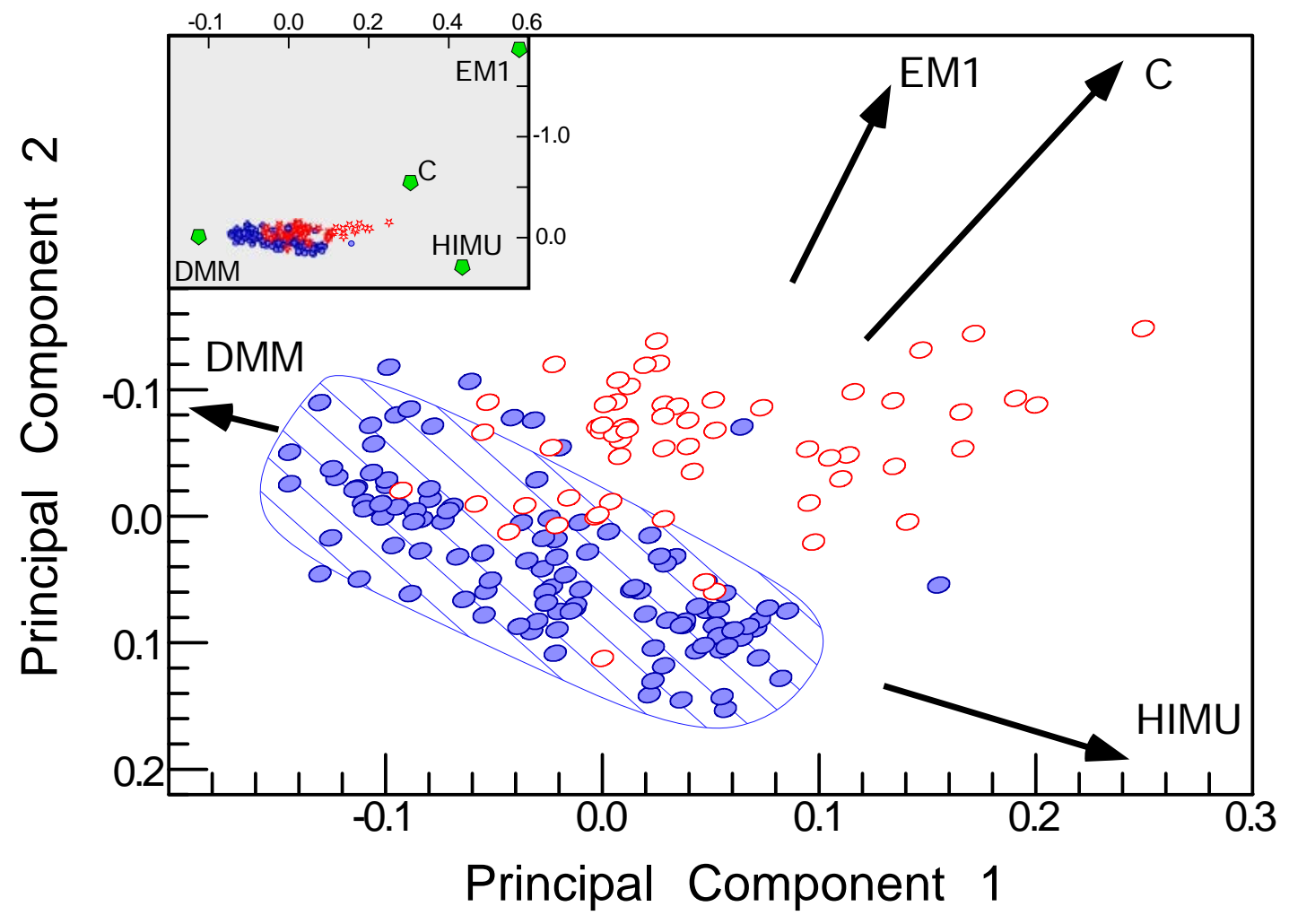




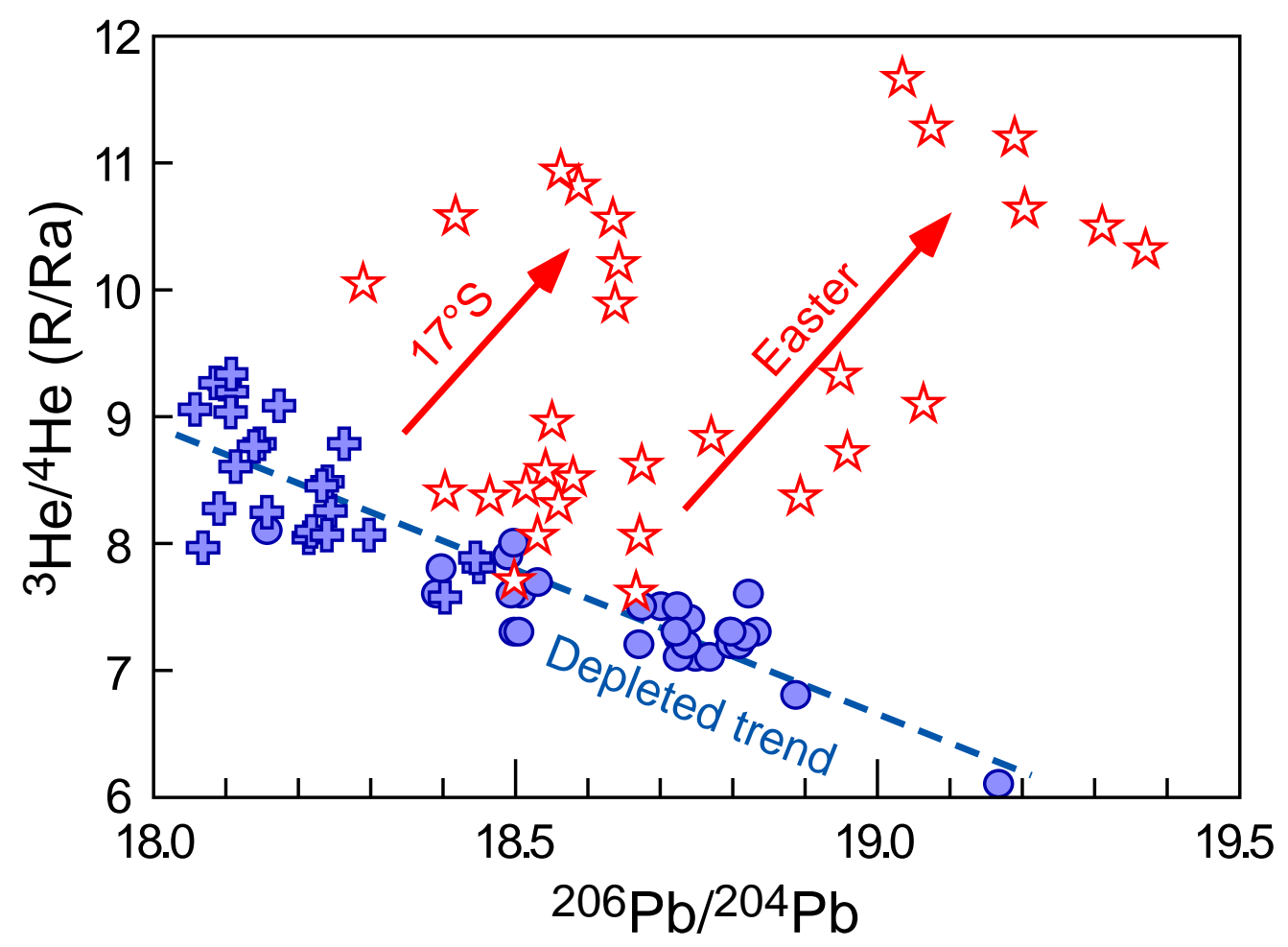


Table 1: Complete $\mathrm{Sr}, \mathrm{Nd}, \mathrm{Pb}, \mathrm{Hf}$ and He isotope data table for PACANTARCTIC 1 and 2 samples. In italic font, previously published data (Vlastélic et al., 1999; Vlastélic et al., 2000; Moreira et al., 2008; Hamelin et al., 2010).

\begin{tabular}{|c|c|c|c|c|c|c|c|c|c|c|c|c|}
\hline & ${ }^{87} \mathrm{Sr} /{ }^{86} \mathrm{Sr}$ & ${ }^{143} \mathrm{Nd} /{ }^{144} \mathrm{Nd}$ & $\varepsilon_{\mathrm{Nd}}$ & ${ }^{206} \mathrm{~Pb} /{ }^{204} \mathrm{~Pb}$ & ${ }^{207} \mathrm{~Pb} /{ }^{204} \mathrm{~Pb}$ & ${ }^{208} \mathrm{~Pb} /{ }^{204} \mathrm{~Pb}$ & ${ }^{176} \mathbf{H f} /{ }^{177} \mathbf{H f}$ & $\varepsilon_{\mathrm{Hf}}$ & ${ }^{3} \mathrm{He} /{ }^{4} \mathrm{He}$ & Long. $\left(^{\circ}\right)$ & Lat. $\left({ }^{\circ}\right)$ & Depth \\
\hline \multicolumn{13}{|c|}{ PACANTARCTIC 2} \\
\hline 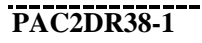 & $0 . \overline{0} 24 \overline{6} 5$ & $0.51310 \overline{8}$ & $9.17^{-}$ & 18.671 & 15.533 & 38.039 & $0 . \overline{2} 8 \overline{1} \overline{1} \overline{5}$ & $12 . \overline{50}$ & $7 . \overline{2}^{-}$ & $-11 \overline{1} .3$ & -41.80 & 2524 \\
\hline PAC2DR37-1 & 0.702462 & 0.513091 & 8.84 & 18.722 & 15.540 & 38.110 & 0.283106 & 11.80 & 7.3 & -111.3 & -42.27 & 2475 \\
\hline PAC2DR37-2 & & & & & & & 0.283118 & 12.25 & 7.3 & -111.3 & -42.27 & 2475 \\
\hline PAC2DR36-1 & 0.702479 & 0.513066 & 8.34 & 18.724 & 15.538 & 38.117 & 0.283119 & 12.27 & 7.5 & -111.6 & -42.95 & 2503 \\
\hline PAC2DR35-1a & & & & & & & 0.283121 & 12.34 & 7.2 & -111.8 & -43.59 & 2463 \\
\hline PAC2DR35-2 & 0.702492 & 0.513097 & 8.95 & 18.736 & 15.550 & 38.146 & 0.283127 & 12.54 & 7.2 & -111.8 & & 2463 \\
\hline PAC2DR34-1 & 0.702392 & 0.513108 & 9.17 & 18.798 & & & 0.283145 & 13.20 & 7.3 & -112.0 & & 2467 \\
\hline PAC2DR33-1 & 0.702488 & 0.513082 & 8.66 & 18.817 & 15.562 & 38.236 & 0.283111 & 11.99 & 7.26 & -112.3 & & 2374 \\
\hline PAC2DR32-1 & 0.702516 & 0.513078 & 8.58 & 18.809 & 15.539 & 38.202 & 0.283100 & 11.60 & 7.2 & -112.4 & & 2384 \\
\hline PAC2DR31-3 & 0.702479 & 0.513066 & 8.36 & 18.833 & 15.554 & 38.242 & 0.283112 & 12.03 & 7.3 & -112.7 & & 2414 \\
\hline PAC2DR30-1 & 0.702472 & 0.513060 & 8.24 & 18.887 & 15.565 & 38.311 & 0.283106 & 11.83 & 6.8 & 2.9 & & 2345 \\
\hline PAC2DR29-1 & 0.702504 & 0.513059 & 8.22 & 18.798 & 15.538 & 38.208 & 0.283117 & 12.19 & 7.2 & -113.1 & & 2407 \\
\hline PAC2DR28-2 & 0.702468 & 0.513070 & 8.43 & 18.725 & 15.539 & 38.121 & 0.283102 & 11.66 & 7.1 & -113.3 & & 2489 \\
\hline PAC2DR27-1 & 0.702643 & 0.513035 & 7.74 & 19.168 & & 38. & 0.283094 & 11.37 & 6.1 & & & 2359 \\
\hline PAC2DR22-1 & 0.702465 & 0.513100 & 9.01 & 18.726 & & 38. & 0.283131 & 12.69 & 7.25 & & & 2413 \\
\hline PAC2DR22-3 & 0.702468 & & & 18.761 & 15.540 & 38.202 & 0.283130 & 12.68 & & -11 & & 2413 \\
\hline PAC2DR21-2 & 0.702483 & 0.513088 & 8.78 & 18.768 & 15.544 & 38.189 & 0.283125 & 12.48 & 7.1 & & & 2339 \\
\hline PAC2 & 0.702499 & 0.513088 & 8.78 & 18.768 & 15.540 & 38.202 & 0.283122 & 12.37 & & 7.0 & & 2380 \\
\hline PAC2DR9-2 & & & & 18.798 & 15.552 & 38.244 & 0.283132 & 12.73 & & & & 2380 \\
\hline R20-1 & 0.702493 & 0.513092 & 8.86 & 18.749 & & & 0.283126 & 12.51 & 7.1 & & & 2441 \\
\hline PA & 0.702483 & 0.513077 & 8.56 & 18.7 & & & & 12.74 & 7.3 & & & 2221 \\
\hline PAC & & & & 18.6 & & & 140 & 13.03 & & & & 2221 \\
\hline $27-4$ & 0.702449 & 0.513088 & 8.78 & 18.7 & & & 135 & 12.84 & 7.4 & & & 2229 \\
\hline R6-1 & 0.702518 & 0.513094 & 8.90 & 18.7 & & 38.201 & 0.283133 & 12.75 & & & & 2610 \\
\hline R6-6 & 0.702396 & 0.513099 & 8.99 & 18.696 & 15.537 & 38.123 & 0.283143 & 13.12 & & 7.2 & & 2610 \\
\hline R5-2g & 0.702524 & 0.513098 & 8.97 & 18.674 & 15.537 & 38.110 & 0.283135 & 12.85 & 7.5 & -117.4 & & 2784 \\
\hline PAC2DR4-2 & 0.702367 & 0.513134 & 9.68 & 18.531 & 15.513 & 37.942 & 0.283163 & 13.83 & 7.7 & -117.8 & & 2409 \\
\hline & & & & & & & 0.283139 & 12.97 & 7.5 & & & 2397 \\
\hline R3-3 & 0.702382 & 0.513112 & 9.25 & 18.701 & 15.526 & 38.092 & 0.283143 & 13.12 & 7.5 & & & 2397 \\
\hline & 0.702417 & 0.513116 & 9.32 & 18.724 & 15.530 & 38.110 & 0.283141 & 13.06 & & & & 2405 \\
\hline PAC2DR1-1 & 0.702422 & 0.513090 & 8.81 & 18.822 & 15.547 & 38.199 & 0.283133 & 12.75 & 7.6 & -118.4 & & 2323 \\
\hline \multicolumn{13}{|c|}{ PACANTARCTIC 1} \\
\hline & $0 . \overline{0} 2 \overline{5} \overline{8}$ & $0.5 \overline{1} 3 \overline{1} \overline{8} \overline{8}$ & 9.75 & $1 \overline{8} . \overline{494}$ & 15.489 & 38.100 & $0 . \overline{2} \overline{3} \overline{3} 2 \overline{5}$ & 16.02 & 7.6 & -145.09 & -56.00 & 2617 \\
\hline & 0.702530 & 0.513102 & 9.05 & 18.7 & & & & 15.63 & & & & 2617 \\
\hline & 0.702557 & 0.51 & 9.62 & & & & & 15.77 & & & & 2617 \\
\hline $3-2 g$ & 0.702556 & 0.513142 & 9.82 & 18.508 & & & 3204 & 15.28 & 7.6 & & .57 & 2674 \\
\hline $13-3$ & 0.702570 & 0.513145 & 9.89 & 18.508 & 505 & 963 & 3200 & 15.14 & & -145. & .57 & 2674 \\
\hline PAC1DR12-1g & 0.702310 & 0.513150 & 9.99 & 18.064 & 15.467 & 37.468 & 0.283235 & 16.37 & & -146.29 & -57.18 & 2539 \\
\hline PAC1DR12-3g & 0.702375 & 0.513146 & 9.91 & 18.194 & & & 3217 & 15.74 & & -146.29 & 57.18 & 2539 \\
\hline PAC1DR12-3r & 0.702395 & 0.513170 & 10.38 & 18.192 & & & 0.283216 & 15.70 & & & & 2539 \\
\hline PAC1DR11-1g & 0.702435 & 0.513125 & 9.50 & 18.420 & & & 0.283171 & 14.11 & & & & 2500 \\
\hline PAC1DR11-3 & 0.702469 & 0.513129 & 9.58 & & & & & 14.50 & & & & 2500 \\
\hline PAC1DR10-1g & 0.702473 & 0.513112 & 9.25 & 18.426 & 15.492 & 37.881 & 0.283149 & 13.33 & & -148.50 & 57.89 & 2319 \\
\hline PAC1DR10-3 & 0.702470 & 0.513127 & 9.54 & 18.400 & 15.483 & 37.798 & 0.283148 & 13.30 & & & & 2319 \\
\hline 1DR09-g & 0.702467 & 0.513120 & 9.40 & 18.638 & & 38.075 & 0.283150 & 13.37 & & & & 2484 \\
\hline PAC1DR09-1 & 0.702372 & 0.513112 & 9.25 & 18.376 & 15.470 & 37.819 & & & & -149.14 & & 2484 \\
\hline & 0.702388 & 0.513110 & 9.21 & & & & & 13.37 & & & & 2365 \\
\hline & 0.702376 & & 9.27 & & & & & 13.33 & 7.8 & & & 2365 \\
\hline & 0.702472 & & 8.99 & & & & & 13.16 & & & & 2362 \\
\hline $7-2 g$ & 0.702454 & 0.513098 & 8.97 & 18. & & & 129 & 12.63 & & & 00 & 2362 \\
\hline 207-3 & 0.702428 & 0.513090 & 8.82 & 18. & & & 3132 & 12.73 & & -152.08 & .00 & 2362 \\
\hline PAC1DR06-g & 0.702502 & 0.513126 & 9.52 & 18.498 & & & 0.283163 & 13.83 & 8 & -153.21 & -60.94 & 2527 \\
\hline PAC1DR06-2 & 0.702389 & 0.513113 & 9.27 & 18.491 & 493 & 912 & 0.283171 & 14.11 & & -153.21 & -60.94 & 2527 \\
\hline PAC1DR05-1g & 0.702407 & 0.513132 & 9.64 & & & & .283168 & 14,00 & & -154.54 & .00 & 2344 \\
\hline PAC1DR05-3 & 0.702435 & 0.513138 & 9.75 & 18. & & & 0.283179 & 14.39 & 7.9 & -154.54 & & 2344 \\
\hline PAC1DR05-r & 0.702455 & 0.513122 & 9.44 & & & & 0.283183 & 14.53 & & -154.54 & -62.00 & 2344 \\
\hline PAC1DR03-1 & 0.702421 & 0.513107 & 9.15 & 18.505 & 15.498 & 37.974 & 0.283152 & 13.44 & 7.3 & -156.08 & -62.32 & 2219 \\
\hline PAC1DR03-2 & 0.702439 & 0.513106 & 9.13 & 18.498 & 15.494 & 37.965 & 0.283147 & 13.26 & 7.3 & -156.08 & -62.32 & 2219 \\
\hline PAC1DR02-g & 0.702335 & 0.513141 & 9.81 & 18.272 & & 7.837 & 0.283189 & 14.75 & & -156.54 & -62.64 & 2489 \\
\hline PAC1DR02-1 & 0.702362 & 0.513147 & 9.93 & 18.369 & 15.498 & 37.860 & 0.283186 & 14.64 & & -156.54 & -62.64 & 2489 \\
\hline PAC1CV09 & 0.702370 & 0.513110 & 9.21 & 18.236 & & & 0.283139 & 12.98 & & -159.61 & -62.66 & 2714 \\
\hline PAC1CV08 & 0.702419 & 0.513112 & 9.25 & & & & 0.283126 & 12.52 & & & -62.77 & 2534 \\
\hline & 0.702362 & & 9.56 & & & & & 14.04 & & & & 2755 \\
\hline PAC1CV06-g & 0.702397 & 0.513129 & 9.58 & & & & 0.283172 & 14.15 & & & -63.45 & 2755 \\
\hline PAC1CV04-g & 0.702512 & 0.513144 & 9.87 & 18.157 & & & 0.283173 & 14.18 & 8.1 & -169.40 & & 2340 \\
\hline PAC1CV03-r & 0.702423 & 0.513109 & 9.19 & & & & 0.283173 & 14.18 & & & & 2576 \\
\hline & 0.702406 & 0.513117 & 9.34 & & & & 0.283170 & 14.07 & & -171.88 & -64.53 & 2576 \\
\hline & 0.702568 & & 9.69 & & & & 0.283175 & 14.25 & 7.6 & -172.43 & -64.83 & 2936 \\
\hline & 0.702551 & 0.513153 & 10.05 & 18.447 & & & 0.283156 & 13.58 & & -173.75 & -65.10 & 2863 \\
\hline PAC1CV01-g & 0.702597 & 0.513124 & 9.48 & 18.761 & 15.591 & 38.549 & 0.283144 & 13.16 & & -173.75 & -65.10 & 2863 \\
\hline
\end{tabular}




\section{Supplementary Material}

\section{New algorithm to compute a PCA:}

The PCA method is a linear transformation that converts the data into a new coordinate system in which the direction along which the greatest data variance is expressed, becomes the first axis (PC1). The direction along which the greatest data variance is expressed orthogonal to PC1 becomes the second axis (PC2), and so on. The first step, called the whitening, consists in normalizing the data. This is done by subtracting the mean value from each data point and dividing the result by the standard deviation of each variable. The correlation matrix (Pearson's correlation matrix) of the reduced variables can then be calculated. The next step consists into diagonalizing the correlation matrix in order to find the eigenvalues, which correspond to the dimensions that have the strongest correlation in the data set. The principal components are the coordinates of the data points in the eigenvector referential.

The PCA method used with our geochemical dataset has been initially developed for low-rank matrix approximations (Srebro and Jaakkola, 2003) and was recently adapted for tectonic problems using incomplete geodetic times series (Kositsky and Avouac, 2010). The algorithm used to compute our principal components has been written specifically to address the major problem of a geochemical database: missing data in the matrix. Traditionally, for a given sample, it is necessary to acquire as many different isotope measurements as the number of dimensions used in the PCA. The paucity of combined $\mathrm{Sr}-\mathrm{Nd}-\mathrm{Pb}-\mathrm{Hf}$ isotope data in individual samples is therefore an important issue for standard PCA algorithms. The more dimensions we use in the PCA, the fewer samples meet the required conditions: from 210 samples for 2-dimension $(\mathrm{Sr}-\mathrm{Nd})$ space to only 99 samples for a 6-dimension space. The main difference with a classical PCA is that we have replaced the standard Singular Value Decomposition (SVD) with a more sophisticated decomposition proposed by Srebro and Jaakkola [2003]. In this approach the data matrix $\mathrm{X}$ is decomposed into components $\mathrm{U}, \mathrm{S}, \mathrm{V}$, with each data point weighted according to the square of its standard error. This decomposition is particularly adapted to take into account individual measurement errors and deal with missing data points. It allows us to compute the Principal Components on the entire data set, even if some isotopic ratios are missing. Each missing data point is weighted with infinite standard error. We want to emphasize that, consequently, no interpolation is made, which could erase some local effect. This technique is particularly suitable to geochemical data as it allows us to complete the principal components using the whole dataset, increasing therefore the accuracy of the calculation. 


\section{Limits of PCA:}

\section{Classical limits related to PCA calculation:}

Because the PCA method is an orthogonal linear transformation, it assumes the linearity of the data co-variations. In most binary isotopic diagrams, mixing processes are expressed by hyperboles whose curvatures depend on the elemental concentration ratios of the involved end-members. But in the case of MORB, pseudo-linear correlations are observed (Fig. 2) indicating that denominator elements are in approximately constant proportions in the mixing components. It is very difficult to evaluate the extent of non-linear relationships concealed within the analytical noise. However, it is interesting to note that the geographical variations of the components calculated with our method are approximately the same as those computed in the 3-dimensional space of $\mathrm{Pb}$ isotopes, in which relationships are linear. In order to minimize the correlations induced by the ${ }^{204} \mathrm{~Pb}$ analytical noise (it represents only about $1.4 \%$ of the total $\mathrm{Pb}$ ), the computation has been made in the ${ }^{204} \mathrm{~Pb} /{ }^{206} \mathrm{~Pb},{ }^{207} \mathrm{~Pb} /{ }^{206} \mathrm{~Pb}$ and ${ }^{208} \mathrm{~Pb} /{ }^{206} \mathrm{~Pb}$ space. Considering the problematic of our study, this observation suggests that the curvature can be neglected.

\section{Limits related to our new algorithm:}

Compared to traditional PCA algorithms, principal components are computed here altogether rather than separately, because the number of components affects the subspace in which these components reside. A limit to this method appears if one variable is represented by fewer samples than compared to other variables. In this particular case, a sample with a value corresponding to this "rare" variable is artificially given more weight. In return, each variable is also weighed in proportion to its number of samples. Because the number of $\mathrm{He}$ isotope analyses along the studied ridge section is too low compared to other isotopes, the information provided by this parameter has not been included in the PCA calculation. 
Distribution of the variance among the principal components:

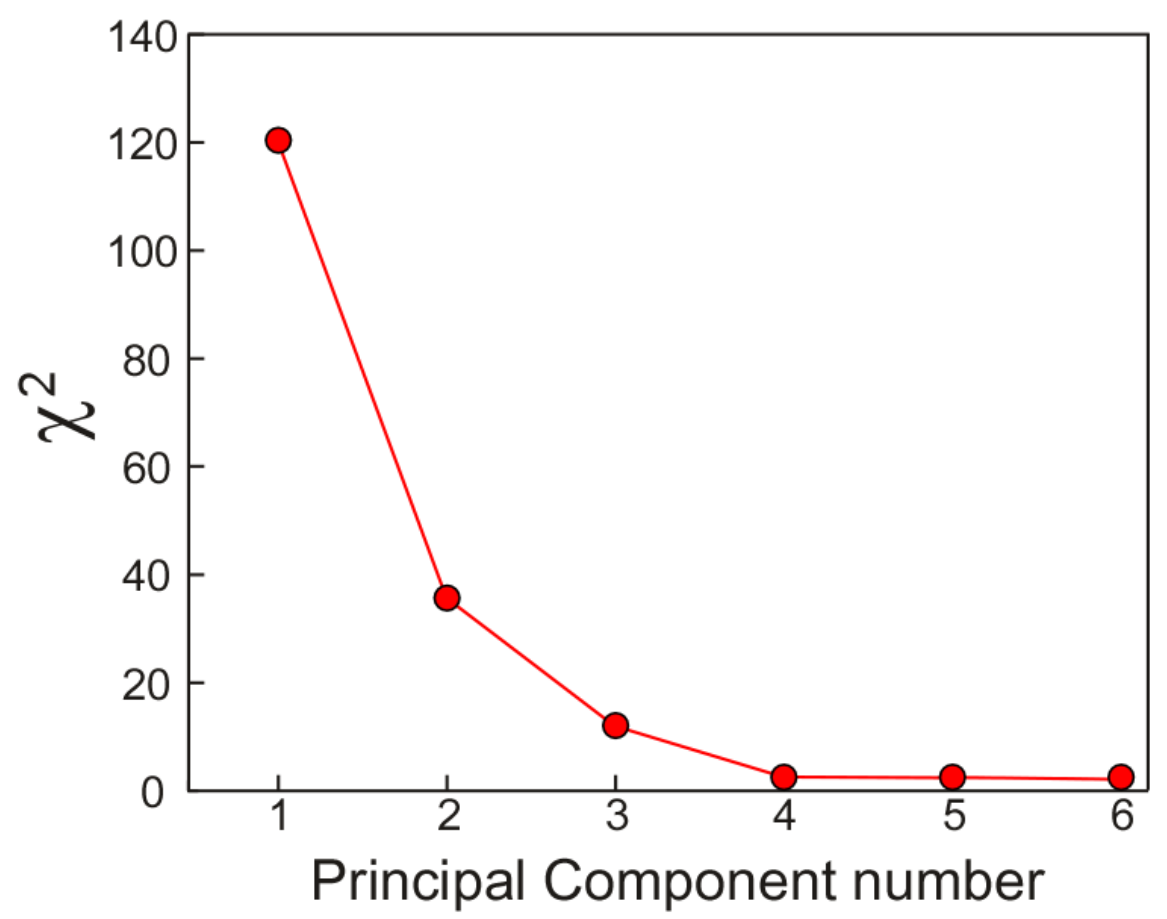

Plot of the residual variance $\left(\chi^{2}\right)$ versus the principal component number

\section{Figure 2 data references:}

Bach, W., Hegner, E., Erzinger, J., Satir, M., 1994. Chemical and isotopic variations along the superfast spreading East Pacific Rise from $6^{\circ} \mathrm{S}$ to $30^{\circ} \mathrm{S}$. Contribution to Mineralogy and Petrology, 116(4): 365-380.

Castillo, P., 1988. The Dupal anomaly as a trace of the upwelling lower mantle. Nature, 336: 667-670.

Fontignie, D., Schilling, J.-G., 1991. 87Sr/86Sr and REE variations along the Easter Microplate boundaries (south Pacific): Application of multivariate statistical analyses to ridge segmentation. Chemical Geology, 89: 209-241.

Hanan, B.B., 1989. Easter Microplate evolution: Pb isotope evidence, Journal Geophysical Research, 94: $7432-7448$.

Kingsley, R.H., Blichert-Toft, J., Fontignie, D., Schilling, J.G., 2007. Hafnium, neodymium, and strontium isotope and parent-daughter element systematics in basalts from the plume-ridge 
interaction system of the Salas y Gomez Seamount Chain and Easter Microplate. Geochem Geophys Geosyst, 8: 28.

Kurz, M.D., Moreira, M., Curtice, J., Lott Iii, D.E., Mahoney, J.J., Sinton, J.M., 2005. Correlated helium, neon, and melt production on the super-fast spreading East Pacific Rise near $17^{\circ} \mathrm{S}$. Earth Planet. Sci. Lett., 232(1-2): 125-142.

Mahoney, J.J., Sinton, J.M., Kurz, M.D., Macdougall, J.D, Spencer, K.J., Lugmair, G.W., 1994. Isotope and trace element characteristics of a super-fast spreading ridge: East Pacific Rise 13$23^{\circ}$ S. Earth Planet. Sci. Lett., 121: 173-193.

Maia, M., C. Hemond and P. Gente 2001. Contrasted interactions between plume, upper mantle, and lithosphere: Foundation chain case. Geochem Geophys Geosyst 2: U25-U53.

Niu, Y.L., Waggoner, D.G., Sinton, J.M., Mahoney, J.J., 1996. Mantle source heterogeneity and melting processes beneath seafloor spreading centers: The East Pacific Rise, 18 degrees-19S. Journal of Geophysical Research, 101(B12): 27711-27733.

Nowell, G.M., Kempton, P.D., Noble, S.R., Fitton, J.G., Saunders, A.D., Mahoney, J.J., Taylor, R.N., 1998. High precision Hf isotope measurements of MORB and OIB by thermal ionisation mass spectrometry: insights into the depleted mantle. Chemical Geology, 149(3-4): 211-233.

Vlastélic, I., Dosso, L., Guillou, H., Bougault, H., Geli, L., Etoubleau, J., Joron, J.L., 1998.

Geochemistry of the Hollister Ridge: relation with the Louisville hotspot and the PacificAntarctic Ridge. Earth Planet. Sci. Lett., 160(3-4): 777-793.

White, W.M., Hofmann, A.W., Puchelt, H., 1987. Isotope geochemistry of Pacific mid-ocean ridge, Journal Geophysical Research, 92: 4881-4893. 